\title{
SUAUGUSIŲJŲ POŽIŪRIS Į FIZINES BAUSMES KAIP I PEDAGOGINĘ ELGESIO KOREKCIJOS PRIEMONE
}

\author{
Daiva Majauskienė, Jolanta Paulauskienè \\ Lietuvos kūno kultūros akademija, Kaunas, Lietuva
}

\begin{abstract}
Daiva Majauskienė. Edukologijos magistrè. Lietuvos kūno kultūros akademijos Kinantropologijos ir sporto raidos katedros asistentė. Mokslinių tyrimų kryptis - XX amžiaus Lietuvos kūno kultūros ir sporto istorijos chronologijos metodologinès problemos.
\end{abstract}

\section{SANTRAUKA}

Suaugusieji turi daug vaiko negatyvaus elgesio korekcijos priemoniu. Jie gali vaikui kantriai paaiškinti, kodèl jo veiksmai yra netinkami ir kokio elgesio tikisi iš savo vaiko arba be komentaru taikyti uvvairias bausmes. Aptarsime tik fizines bausmes, nes nèra vieningos mokslininku nuomonès apie tokiu priemoniu pasekmes vaiko asmenybès raidai, o suaugusieji jas ypač dažnai taiko vaiko elgesio korekcijai.

Tyrimo tikslas - suaugusiuju požiūrio ífizines bausmes, kaip ì pedagoginę elgesio korekcijos priemonę, tyrimas.

Ištirta 100 respondentu imtis (50 vyru ir 50 moteru), sudaryta patogiuoju büdu. Tyrimui atlikti sudarème anketa, remdamiesi viešosios nuomonès ir rinkos tyrimo centro „VILMORUS“ gyventoju apklausos metodika, vaiku patiriamam smurtui tirti (1999). Tyrimo medžiaga analizuota taikant matematinés statistikos metodus. Gautu rezultatu skirtumo patikimumas buvo apskaičiuojamas pagal chi kvadrato $\left(\chi^{2}\right)$ kriteriju, kuris naudojamas hipotezèms apie kintamojo skirstini populiacijoje tikrinti. Pasirinktas patikimumo lygmuo $\alpha=0,05$. Rezultatu skirtumas laikytas reikšmingu, kai $p<0,05$.

Išsiaiškinta, kad fizines bausmes naudoja daugumas tèvu (atitinkamai 52\% vyru ir 78\% moteru) (p < 0,05). Moterys reikšmingai dažniau nei vyrai yra patys patyre fizinę bausmę vaikysteje. Pastaruoju metu pastebima tendencija, kad fiziné bausmé vaikams, kaip elgesio korekcijos priemoné, pasirenkama rečiau. Respondentus tèvai vaikystèje dažniausiai bausdavo už neklusnumq atsikalbinèjima, dingima iš namu, melq. Pagrindinès priežastys, dèl kuriu respondentai baudžia savo vaikus, - atsikalbinèjimas, neklusnumas, melas, blogi pažymiai, prasta tèvu nuotaika. Beveik pusẻ respondentu (58\% vyru ir 48\% moteru) mano, kad fizinès bausmès padeda tapti geresniu žmogumi. Nuomonei, kad fizinès bausmès yra bütina auklèjimo priemonè, prieštarauja $52 \%$ vyru ir $22 \%$ moteru. Tačiau tik trečdalis respondentu (30\% vyru ir 28\% moteru) mano, kad fizines bausmes reikia uždrausti istatymu.

Raktažodžiai: elgesio korekcija, fizinè bausmè, fiziniu bausmiu taikymo priežastys, fiziniu bausmiu pasekmès.

\section{IVADAS}

$\mathrm{K}$ ai kuriose šalyse vienareikšmiškai pasisakoma prieš fizinių bausmių taikymą vaikams. Lietuvoje 1992 m. pasirašyta ir 1995 m. ratifikuota Jungtinių tautu 1989 m. Vaikų teisių konvencija. Tai reiškia, kad Lietuvos Respublika juridiškai i̇sipareigojo saugoti vaikus nuo smurto. Tačiau tinkamai apsaugoti vaiko teises labai sudètinga, nes Vaiko teisių konvencija apima ne tik juridinius, bet ir moralinius standartus (Jonynienè, 2005).

Suaugusieji naudoja ìvairias vaiko elgesio korekcijos priemones. Auklejant vaikus ypač dažnai taikomos fizinès bausmès, nes tėvai neturi laiko bendrauti su vaiku. Suaugusieji neišaiškina vaikui, kaip jis turètų pasielgti susiklosčiusioje situacijoje, o vis dažniau naudoja fizines bausmes. Kitoms auklèjimo priemonèms reikia laiko ir pastangu (Žukauskienè, 2001). Tèvai fizinę bausmę laiko efektyviausia auklejimo priemone, nes reikiamu momentu yra nutraukiamas klaidingas vaiko elgesys (Vaitkienè, 2001).

Fizinè bausmė apibrèžiama kaip fizinès jègos panaudojimas, suteikiantis vaikui fizini skausmą, bet fiziškai nežalojantis norint modifikuoti ar kon- 
troliuoti tam tikrą vaiko elgesi (Straus, 1999). Atlikti tyrimai (Chamberlain, Patterson, 1995) rodo: net $61 \%$ tèvų mano, kad mušimas yra normali bausmè. Sunku nustatyti, ar dažnai tėvai taiko fizines bausmes, nes daugumai tėvų pliaukštelejjimas vaikams ar lengvas mušimas yra tiek iprastas, kad labai greitai pamirštamas ir net nepriskiriamas prie fizinių bausmių (Giles-Sims, Straus, 1995).

Visgi psichologai, pedagogai vis dažniau kalba, kad fizinès bausmès - netinkama elgesio korekcijos priemonè. Net jei vaikų fizinès bausmès nesukelia kūno sužalojimo, jos akivaizdžiai rodo, kad vaikai yra žemesni už suaugusiuosius ir jų nedera gerbti, todèl leidžiama vartoti jègą prieš silpnesniuosius (Gilligan, 2002). Tyrimai patvirtina teiginius ir išvadas, kad suaugusiujų žiaurumo, agresyvumo apraiškos - tai smurto, prievartos pasekmès, susiformavusios jų sąmonèje ir psichikoje dar vaikystejje (Šatas, 1999). Vaikai, kopijuodami tėvų elgesį, darosi agresyvesni, piktesni, nepasitikintys savimi. Daugelis mokslininku pritaria nuomonei, kad fiziniu bausmiu pastovus naudojimas ateityje išprovokuoja agresyvų elgesi (Cole M., Cole S. R., 1996), nuslopina kaltès jausmą (Campbell, 1999). Fizinė bausmė nekeičia vaiko elgesio, o tik trumpam sutramdo vaiką, tačiau po kurio laiko jo neleistinas elgesys vèl pasikartoja (Perecas et al., 1990).

Nepaisant to, kokio amžiaus tarpsniais tėvai taiko fizines bausmes, jos visuomet sukelia negatyvius padarinius ir nubaustajam pateikia atitinkamą elgesio modeli (Valickas, 1993).

Atlikti tyrimai tik patvirtina neigiamus fiziniu bausmiu padarinius: net tik kartais bausti vaikai skiriasi nuo visiškai nepatyrusių fizinių bausmiu asocialesniu elgesiu tiek vaikysteje, tiek suaugus (Grogan-Kaylor, 2004; Slade, Wissow, 2004).

Tyrimų duomenys rodo, kad fizinių bausmių problema aktuali ir užsienyje, ir Lietuvoje. Didžiojoje Britanijoje per mènesi savo sūnus fizinèmis bausmėmis baudè $46,4 \%$ motinu ir $40,7 \%$ tèvuc, dukras - 33,1\% motinu ir 30,6\% tèvų (Nobes, Smith, 1999); JAV 89\% tèvų mušè savo vaikus iki trejų metų, o maždaug trečdalis jų taip ,auklèjo“ savo vaikus tol, kol jiems sukako 15-17 metų; Australijoje motinos mušè $81 \%$ berniuku ir $74 \%$ mergaičiuc, tėvai $-76 \%$ berniuku ir $63 \%$ mergaičių; Airijoje net $86 \%$ suaugusiujų vaikysteje buvo bausti fizinèmis bausmėmis (Šatas, 1999). Lietuvoje šią problemą 1995 m. nagrinėjo VU sutrikusio vystymosi vaikų centras (Smurtas prieš vaikus, 1997), 1996 m. psichologè L. Bulotaitè (1996). 1998 m. organizacija „Gelbėkit vaikus“, vykdydama progra- mą prieš vaikų patiriamą smurta, surengè dvi socialines apklausas, kurias atliko Viešosios nuomonès ir rinkos tyrimo centras „Vilmorus“ (1999).

Tyrimu keliame probleminị klausimą: ar fizinè bausmė yra pozityvi elgesio korekcijos priemonè?

Tyrimo tikslas: suaugusiujų požiūrio į fizines bausmes, kaip i pedagoginę elgesio korekcijos priemonę, tyrimas.

Fizinių bausmių taikymas vaiko negatyvaus elgesio korekcijai, fizinių bausmių taikymo priežastys ir pasekmès - aktuali mokslinių tyrimų, praktiniu diskusijų tema tiek užsienyje, tiek Lietuvoje.

\section{TIRIAMIEJI IR TYRIMO METODIKA}

Tiriamieji. Ištirta 100 respondentu imtis (50 moteru ir 50 vyru), sudaryta patogiuoju būdu. 64\% respondentų turi nepilnamečių vaikų, $36 \%$ vaikai suaugę. Tyrimui buvo parenkami greta esantys asmenys, kuriuos lengva rasti (Kardelis, 2002).

Tyrimo metodai. Remdamiesi viešosios nuomonès ir rinkos tyrimo centro „Vilmorus“ gyventojų apklausos metodika, sudarėme anketą vaikų patiriamam smurtui tirti (1999). Klausimyne buvo pateikti klausimai ir galimi atsakymų variantai apie tai, kaip dažnai tėvai taiko fizines bausmes savo vaikams, kaip suaugusieji vertina fizinių bausmių veiksminguma, ar patys buvo baudžiami vaikystejje, kokios yra jų nuostatos dèl fizinių bausmių.

Statistinè analizė. Tyrimo medžiaga analizuota taikant matematinès statistikos metodus. Gautu rezultatu skirtumo patikimumas buvo apskaičiuojamas pagal chi kvadrato $\left(\chi^{2}\right)$ kriterijų, kuris naudojamas hipotezèms apie kintamojo skirstini populiacijoje tikrinti. Pasirinktas patikimumo lygmuo $\alpha=0,05$. Rezultatų skirtumas laikytas reikšmingu, kai $\mathrm{p}<0,05$.

\section{REZULTATAI}

Atlikus tyrimą paaiškeejo, kad fizines bausmes, kaip elgesio korekcijos priemonę, kartais naudoja dauguma suaugusiujų. $12 \%$ vyrų ir $20 \%$ moteru fizines bausmes naudoja dažnai, $40 \%$ vyru ir $58 \%$ moteru — retai. Taikant $\chi^{2}$ kriterijų nustatyta, kad vyrų ir moterų atsakymai i klausimą „Ar dažnai naudojate fizinę bausmę?" statistiškai patikimai skiriasi $\left(\chi^{2}(2)=7,48 ; p<0,05\right)$ : vyrai nurodé, kad fizinę bausmę jie naudoja rečiau nei moterys.

Vaikysteje $18 \%$ vyru ir $14 \%$ moteru gaudavo i kaili dažnai, $38 \%$ vyru ir $62 \%$ moteru — kartais. Taikant $\chi^{2}$ kriteriju nustatyta, kad vyrų ir moteru 

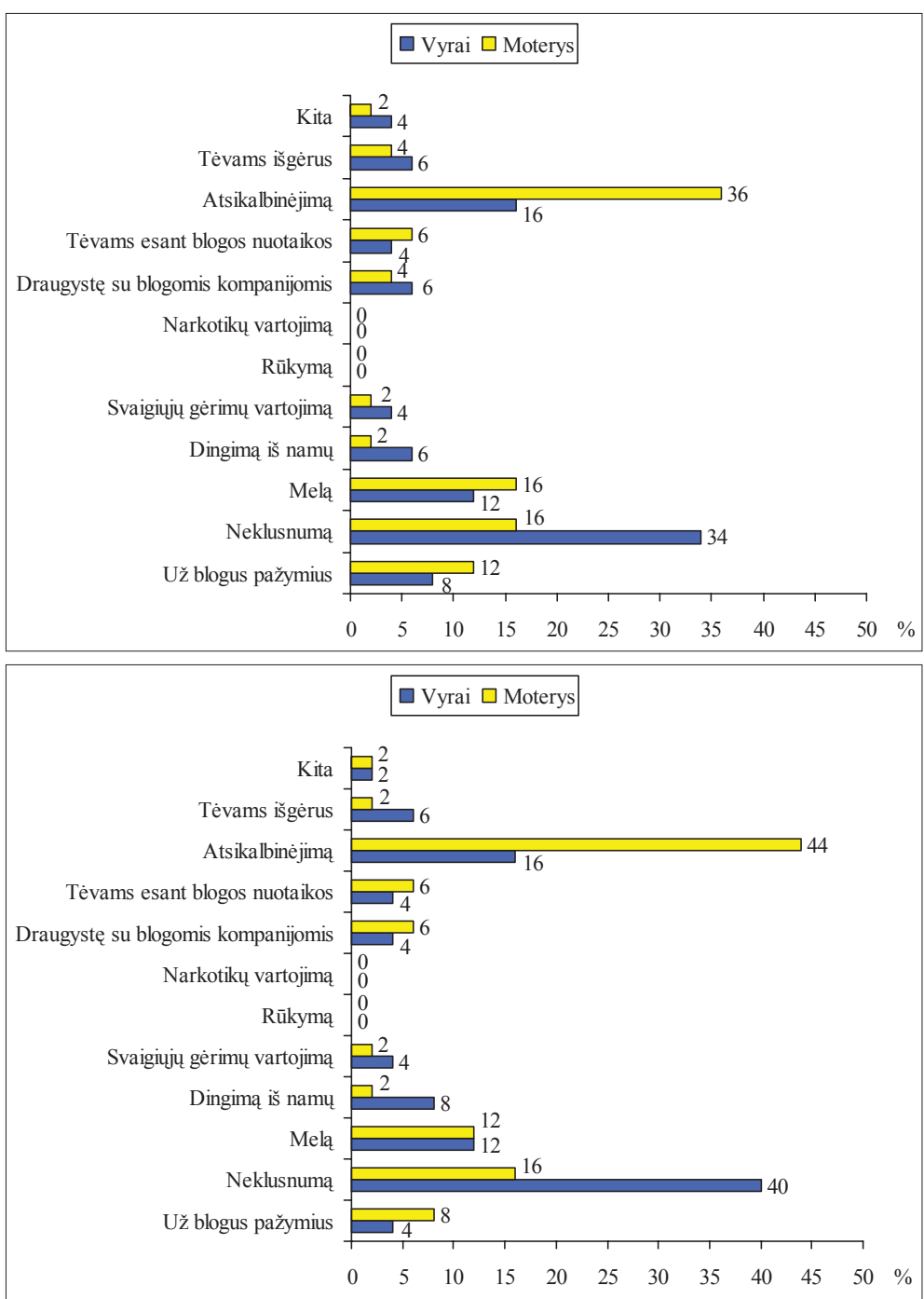

2 pav. Respondentų fizinių bausmių taikymo priežastys savo vaikams

atsakymai i klausimą „Ar dažnai patirdavote fizinę bausmę vaikystèje?" statistiškai patikimai skiriasi $\left(\chi^{2}(2)=6,07 ; p<0,05\right)$ : moterys nurodè, kad fizinę bausmę jos patirdavo dažniau nei vyrai.

Paaiškèjo, kad respondentus dažniausiai mušè ranka arba diržu. Respondentus vaikysteje tèvai žiauriai nemušè nė karto, tačiau dažnai diržu gaudavo $4 \%$ moteru ir $2 \%$ vyrų. Ranka dažnai buvo mušami $10 \%$ moteru bei $16 \%$ vyru. Dažniausiai bausmès buvo naudojamos retai. $40 \%$ moteru ir $30 \%$ vyrų nurodè, kad juos tèvai mušè keletą kartu ranka, 20\% moterų ir 6\% vyru — kad gavo keletą kartų diržu.

Dabar respondentai savo vaikus baudžia taip pat ranka arba diržu. Nè vienas respondentas nenurodè, kad savo vaikus muša labai žiauriai. $48 \%$ moterų ir 34\% vyrų keletą kartų mušè savo vaikus ranka, o $10 \%$ moteru ir $4 \%$ vyrų - diržu. Dažnai muša ranka $16 \%$ moterų ir $10 \%$ vyrų. $2 \%$ moterų ir tiek pat vyrų dažnai ị rankas savo atžaloms auklėti paima diržą.

I klausima, už ką baudè tèvai vaikystëje fizinèmis bausmèmis, respondentai nurodè dvi pagrin-
1 pav. Respondentų fizinių bausmių patyrimo priežastys vaikystèje dines priežastis: neklusnumą - 34\% vyrų ir 16\% moteru, atsikalbinejjimą - $36 \%$ moteru $16 \%$ vyrų. Taikant $\chi^{2}$ kriteriju nustatyta, kad vyru ir moteru atsakymai i klausimą „Už ką baudè tèvai vaikysteje fizinèmis bausmèmis?" statistiškai patikimai skiriasi $\left(\chi^{2}(2)=14,52 ; p<0,05\right)$ : vyrai nurodè fizinę bausmę už neklusnumą taikantys dažniau nei moterys, moterys - už atsikalbinejjimą dažniau nei vyrai. Kitos priežastys nurodytos 1 paveiksle.

Respondentai i klausimą, už ką baudžia savo vaikus fizinèmis bausmèmis, išskyrè dvi priežastis: didesnè dalis vyru (40\%) negu moteru (16\%) paminèjo, kad baudžia už neklusnumą, bet didesnè dalis moterų (44\%) nei vyrų (16\%) statistiškai patikimai $\left(\chi^{2}(2)=10,22 ; p<0,01\right)$ nurode $-u z ̌$ atsikalbinéjimą. Kitos priežastys pateiktos 2 paveikslèlyje.

Pateikus klausimą, „Ar pritartumète nuomonei, kad fizinès bausmès padèjo jums suprasti, kad elgètès blogai?"،, beveik trečdalis respondentu ( $36 \%$ vyrų ir 36\% moterų) atsakè - nepadèjo. $44 \%$ vyru ir $28 \%$ moterų teigè, kad padèjo, $36 \%$ moteru ir $20 \%$ vyru - kartais padejjo. 
3 pav. Respondentų požiūris į fizinių bausmių, kaip auklèjimo priemonès, būtinumą

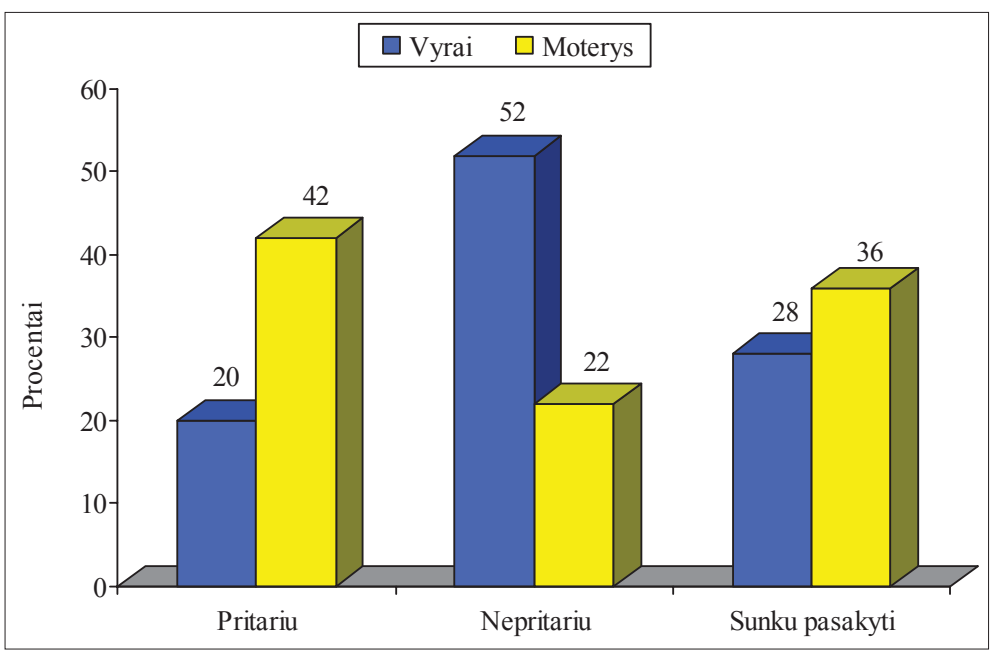

4 pav. Respondentų nuostatos į fizinių bausmių uždraudimą įstatymu

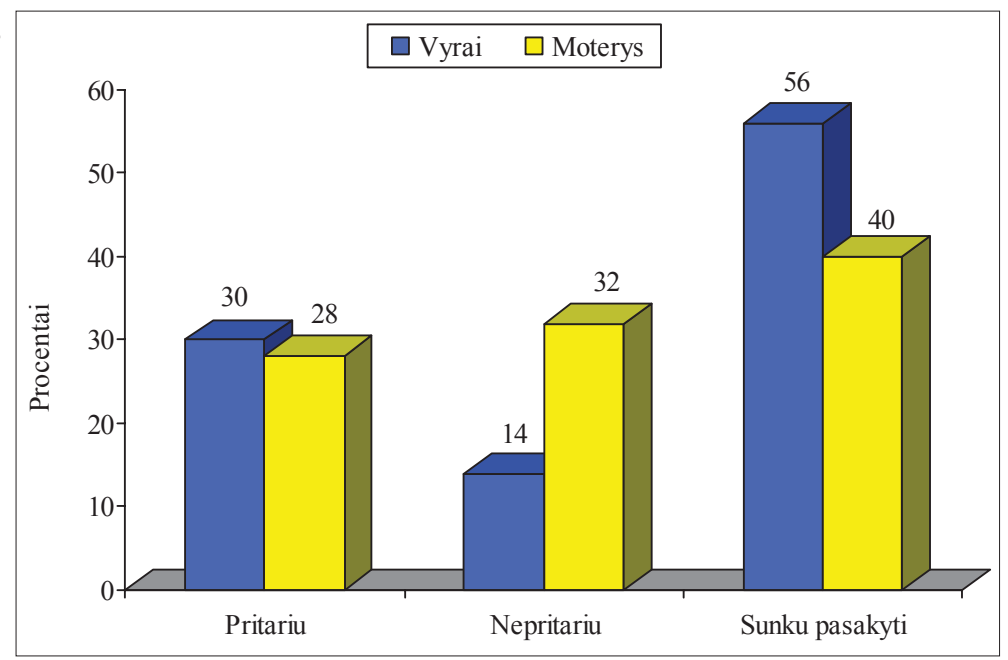

Nustatyta, kad po patirtos fizinès bausmès daugiausia vyru pyko (36\%), maištavo (25\%), jautèsi ižeisti (18\%), moterys labiausiai jautèsi ižeistos (34\%), pyko (21\%), verkè (18\%). Tik 3\% moteru ir 4\% vyrų teige, kad jie buvo nusipelnę fizinès bausmès. Net $13 \%$ moteru ir $11 \%$ vyrų mano neprasikaltę taip, kad prieš juos būtų panaudota fizinè bausmè.

Didesnè dalis respondentų mano, kad fizinès bausmès padeda tapti geresniu žmogumi (taip nurode $58 \%$ vyru ir $48 \%$ moteru). Beveik penktadalis respondentu ( $18 \%$ vyrų ir $24 \%$ moteru) teigè, $\mathrm{kad}$ fizinès bausmès nepadeda tapti geresniu žmogumi.

Respondentų požiūris į fizinių bausmių, kaip auklèjimo priemonès, būtinumą matyti 3 paveikslèlyje. Taikant $\chi^{2}$ kriterijų nustatyta, kad vyrų ir moterų atsakymai i klausimą „Ar pritartumète nuomonei, kad fizinè bausmè yra būtina auklejjimo priemonė?" statistiškai patikimai skiriasi $\left(\chi^{2}(2)=10,48\right.$; $\mathrm{p}<0,01)$ : vyru daugiau nei moteru nurodè, kad fizinè bausmè yra būtina auklejjimo priemonè.

Nustatyta, kad didžioji dalis vyrų ir moterų nežino, ar verta fizines bausmes uždrausti įstatymu (4 pav.).

\section{REZULTATŲ APTARIMAS}

Vaikų mušimas - gana įprastas reiškinys Lietuvoje. Pedagogo J. Geniušo nuomone, apie $80 \%$ tèvų vis dar muša vaikus (Vaitkienè, 2001). Atliktas tyrimas patvirtino, kad dauguma respondentų naudoja fizines bausmes kaip vaikų elgesio korekcijos priemonę. Beveik pusė apklaustujų jas naudoja retai, $16 \%$ dažnai ir beveik trečdalis ju nenaudoja.

Smurtas prieš vaikus, iprotis mušti juos ranka, diržu, rykšte - nuo seno plačiai paplitęs reiškinys (Vaitkienè, 2001). Tyrimas patvirtino, kad respondentus tèvai dažniausiai bausdavo diržu ir ranka, o dabar suaugusieji savo vaikus dažniausiai „auklèja“ taip pat diržu ir ranka.

Pamėgdžiojant savo tèvus, agresyvus elgesys gali būti perduodamas iš kartos ị kartą (Valickas, 1993). Tẻvai, patyrę fizines bausmes vaikysteje, pateisina savo tèvų elgesî, ir tai tik didina tikimybę, kad ir jie patys baus savo vaikus už neklusnų elgesi: ,Jeigu mane tèvai baudè mušdami už neklusnumą ir aš tapau normaliu žmogumi, tai kodèl turèčiau nemušti savo vaiko, kai jis neklauso?" 
(Jusienè, 2006). Daugelis tèvų muša vaikus, „nes kažkada vaikystejje juos pačius mušè ir žemino, jie patys kažkada patyrẻ didelių nuoskaudų“ (Gurtler, 2002). Pusè tirtuju nurodé, kad vaikysteje patirdavo fizinę bausmę retai, $16 \%$ dažnai ir tik trečdalis fizinių bausmiu nepatyrè.

Pagrindinès fizinių bausmių priežastys: suaugusieji griebiasi fizinių bausmiu norèdami išlieti savo pyktį, neviltị, bejègiškumą, kilusi iš kitur; siekdami pakeisti vaiko elgesi; nemokèdami komunikuoti savo jausmais, paradoksaliai reikšdami vaikui savo meilę ar globą; apskritai nerasdami kitu priemonių artumui pasiekti (Laurinaitis, 1996). D. Pūras mano, kad fizinių bausmių priežastis yra skurdas, nes jis gimdo nevilti pažeminimą, pyktị. Dalis tėvų naudoja fizines bausmes, nes nežino kitokių drausminimo būdų, nežino, kaip kontroliuoti vaiką, nustatyti jo elgesio ribas nenaudojant prievartos (Tamošiūnienè, 1999; Civinskas ir kt., 2006). Sunkus vaiko temperamentas, raidos sutrikimai arba kitos jau esančios elgesio problemos gali nulemti tai, kad tevai griebiasi fizinių bausmių ugdydami tokius vaikus (Culp et al., 1999; Mathoney et al., 2000). Tyrimo metu respondentai nurodè, kad vaikysteje jie dažniausiai buvo baudžiami už neklusnumą, atsikalbinèjimą, melą. Dabar jie fizines bausmes taip pat dažniausiai taiko už neklusnumą, atsikalbinėjimą.

Fizinès bausmès nepakeičia vaiko elgesio, o tik trumpam sutramdo vaika, tačiau po kurio laiko neleistinas elgesys vèl pasikartoja (Perecas ir kt., 1990). Dauguma respondentų i̇sitikinę: fizinès bausmès padeda arba kartais padeda suprasti, kad buvo pasielgta blogai ir tik trečdalis mano priešingai.

Visos bausmès yra žalingos, nes jos sukelia ivairių kančių, išgyvenimų, sumažina žmogaus laimés pojūtị ir nustato vaiką prieš auklèjimą, gimdo blogus santykius tarp tèvu ir vaikų, kartais skatina ir stiprina vaiko norą dar daugiau nusižengti (Bajoriūnas, 1997). Amerikiečių psichoterapeutas R. Sneideris išskiria dvi pagrindines fizinių bausmiu pasekmes: fizini skausmą ir pažeistą vaiko psichika, nes jis jaučiasi pažemintas, kyla keršto ir baimès jausmas. Mušimas išprovokuoja vaiko apsimetinejjimą, pagiežą, bailumą ir veidmainiavimą, pataikavima, melą, o visa tai slopina vaiko sąžinès raidą (Miškinis, 2003). Fizinių bausmių naudojimas vaikus moko, kad smurtinis, agresyvus elgesys yra priimtinas, norint užsitarnauti kitu pagarbą ir pelnyti autoritetą (Vaiku linija). Nors kai kurie tyrèjai, remdamiesi tyrimu rezultatais, teigia, kad jokios žalos nėra, jeigu fizinès bausmès taikomos retai, o tèvai yra vaiką mylintys ir rūpestingi (Baumrind et al., 2002). Respondentai nurodè, kad patyrę fizinę bausmę dažniausiai pyko, jautèsi įžeisti.

Tarp pedagogų, psichologų vyrauja keli požiūriai i fizines bausmes: vieni (J. Dobson) teigia, kad fizinès bausmès yra gera auklëjimo priemoné, kiti (Perecas ir kt., 1990; Valickas, 1993; Cole M., Cole S. R., 1996; Geniušas, 1996) griežtai nusiteikę prieš fizinių bausmių naudojimą auklèjimo procese, treti (Campbell, 1999) blogiausiu atveju auklèjant vaikus neatmeta ir fiziniu bausmių, ketvirtieji (Peters, 1999) mano, kad vaikus drausminti reikia atsižvelgiant i jų amžių, galimybes ir būdą. Tyrimo rezultatai parodé, kad dauguma respondentu pritaria R. Campbell nuomonei ir mano, jog fizinè bausmé padeda tapti geresniu žmogumi, ir tik penktadalis mano priešingai. Paaiškejjo, kad daugiau vyrų negu moteru (atitinkamai 58\% ir 48\%) galvoja, kad fizinès bausmès turi teigiamos itakos.

Daugiau respondentų (22\% moteru ir $52 \%$ vyrų) nepritaria nuomonei, kad fizinès bausmès yra būtina auklejjimo priemonè, tačiau beveik trečdalis (20\% vyrų ir 42 moteru) mano priešingai.

Švedija pirmoji 1979 m. paskelbè, kad „vaikas neturi patirti jokios fizinès bausmès ar kitokio žeminančio ar žalojančio elgesio“ (Durrant, 2003). Netrukus šios valstybės pavyzdžiu paseke kitos šalys: Suomija, Danija, Norvegija, vèliau Austrija, Belgija, Danija, Islandija, Italija, Izraelis, Kipras, Kroatija, Latvija, Vokietija (Freeman, 1999; Durrant, 2003; Kadzin, Benjet, 2003). 2006 m. Monake vykusioje konferencijoje „Kuriame Europą vaikams ir su vaikais", apskritojo stalo diskusijos dèl „Europos laisvos nuo fizinių bausmių“ metu buvo pastebèta, kad visos šalys turi uždrausti (ir fizines, ir psichologines) visose institucijose ir vietose, kur gyvena vaikai. Konferencijoje paminèta, kad tik trečdalis šalių nariu jau uždraudusios fizines bausmes savo šalyse (Lietuvos Respublikos vaiko teisiu apsaugos kontrolieriaus istaiga, 2006). Lietuva nuo 1992 metu yra juridiškai įsipareigojusi saugoti vaikus nuo smurto, tačiau fizinès bausmès nèra uždraustos. Fizinių bausmių uždraudimui istatymu prieštarauja beveik ketvirtadalis tirtuju. Be abejo, retas respondentas susimąstè, kad priimtasis ístatymas gintų labiausiai skriaudžiamus vaikus ir padidintų suaugusiuju atsakomybę už elgesi su vaikais. Suaugusieji būtų priversti domètis ir ieškoti kitokių auklejjimo metodų. Tèvai, spręsdami problemas, daugiau bendradarbiautu su mokyklų pedagogais, dažniau kreiptusi kvalifikuotos pagalbos i Saugaus vaiko centrą (Saugaus vaiko centras), Paramos vaikams centrą (Paramos vaikams centras) Pedagogines-psichologines tar- 
nybas (Pedagoginis psichologinis centras). Be to, toks istatymas padrąsintu vaikus ir tėvus kurti bei palaikyti naują vertybių sistemą.

\section{IŠVADOS}

Nustatyta, kad fizines bausmes kaip tinkamą vaikų elgesio korekcijos priemonę pripažista dauguma suaugusiuju ( $52 \%$ vyrų ir $78 \%$ moteru). Pastaruoju metu pastebima tendencija, kad fizinè bausmè vaikams, kaip elgesio korekcijos priemonè, pasirenkama rečiau. Bausmes tėvai dažniausiai naudoja kartais.

Didžiausi prasižengimai, už kuriuos vaikai buvo baudžiami fizine bausme, - neklusnumas, atsikalbinejjimas, melas, blogi pažymiai ir prasta tèvų nuotaika. Dabar suaugusieji fizines bausmes, kaip elgesio korekcijos priemonę, naudoja taip pat už neklusnumą ir atsikalbinejjimą.

Trečdalis respondentų teigè, kad fizinès bausmès nepadejo suprasti, jog buvo elgtasi blogai, penktadalis - kad nepadeda tapti geresniu žmogumi. $37 \%$ nepritaria nuomonei, kad fizinès bausmès yra būtina auklejjimo priemonè.

Beveik ketvirtadalis respondentų (14\% vyrų ir $32 \%$ moteru) mano, kad fiziniu bausmiu nereikia uždrausti i̇statymu, beveik trečdalis $(30 \%$ vyrų ir $28 \%$ moterų) mano priešingai, didžioji dalis apklaustujų neapsisprendę.

\section{LITERATŪRA}

Bajoriūnas, Z. (1997). Šeimos edukologija. Vilnius: Jošara.

Baumrind, D., Larzelere, R. E., Cowan, P. A. (2002). Ordinary physical punishment: Is it harmful? Psychological Bulletin, Vol. 128, 4, 580-589.

Bulotaite, L. (1996). Alkoholizmu sergančiuju šeimu vaikai. Vaiku fizine ir seksualine prievarta. Kaunas.

Campbell, R. (1999). Kaip iš tikruju mylèti savo vaika. Kaunas.

Campbell, R. (2000). Vaikai pavojuje. Kaip padèti vaikui nugaleti pykti. Kaunas.

Chamberlain, P., Patterson, G. R. (1995). Discipline and child compliance in parenting. Handbook of Parenting, Vol. 4, 205-227.

Civinskas, R., Levickaite, V., Tamutienè, I. (2006). Vengiančiu lankyti mokykla vaiku problemos ir poreikiai. Vilnius: Garnelis.

Cole, M., Cole, S. R. (1996). Development of Children. New York: N. H. Freman and company.

Culp, R. E., MacDonald Culp, A., Dengler, B., Maisano, P. S. (1999). First-time young mothers living in rural communities use corporal punishment with their toddlers. Jornal of Community Psyhology, Vol. 27, 4, 503-509.

Durrant, J. E. (2003). Legal reform and attitudes toward physical punishment in Sweden. The International Journal of Children's Rights, Vol. 11, 147-173.

Freeman, M. (1999). Children are unbeatlable. Children and Society, Vol. 13, 130-141.

Geniušas, J. (1996). Ar galima mušti vaikus? Rinktiniai pedagoginiai raštai. Kaunas.

Giles-Sims, J., Straus, M. A. (1995). Child, maternal, and family characteristics associated with spanking. Family Relations, Vol. 44, 170-186.

Gilligan, J. (2002). Smurto prevencija. Vilnius: Eugrimas.

Grogan-Kaylor, A. (2004). The effect of corporal punishment on antisocial behavior in children. Social Work Research, Vol. 28, 3, 153-162.

Gurtler, H. (2002). Strafen und Folgen. Berlin: Verlag Urania.

Jonynienè, Ž. (2005). Vaiko teisiu igyvendinimo Lietuvoje aktualijos. Acta Paedagogica Vilnensis: mokslo darbai, $15,129-142$.

Jusienè, R. (2006). Fizinių bausmių taikymas šeimoje ugdant vaikus: tèvų požiūris ir galimos priežastys. Socialinis darbas, 5 (1), 63-71.

Kadzin, A. E., Benjet, C. (2003). Spanking children: Evidence and issues. Current Directions in Psychological Sciencie, Vol. 12, 3, 99-103.

Kardelis, K. (2002). Mokslinių tyrimų metodologija ir metodai. Kaunas: Judex.

Laurinaitis, E. (1996). Prievarta kaip egzistencijos problema. Vaiku fizinè ir seksualine prievarta. Vilnius.

Lietuvos Respublikos vaiko teisiu apsaugos kontrolieriaus istaiga. (2006). Prieiga per internetą: http://vaikams.lrs. lt/informaciniai2006/Monakas-04-04.htm

Mathoney, A., Donnelly, W. O., Lewis, T., Maynard, C. (2000). Mother and father self-reports of corporal punishment and severe physical agression toward clinicreffered youth. Journal of Clinical Child Ppsychology, Vol. 29, 2, 266-281.

Miškinis. K. (2003). Šeima žmogaus gyvenime. Kaunas: Aušra.

Nobes, G., Smith, M. (1999). Physical punishment by mothers and fathers in British Homes. Journal of Interpersona, Vol. 8, 16.

Paramos vaikams centras. Prieiga per internetą: http:// www.pvc.lt $/$ main.php?id=5\&idd=5\&lan=1t versija

Pedagoginis psichologinis centras. Prieiga per internetą: www.pprc.1t/ktpp/archyvas/ 2000-2001/Svcentrai_ 2001/22_pedag.htm

Perecas, M., Minzel, B., Vimeris, H. (1990). Ką turètų žinoti tèvai. Kaunas.

Peters, R. (1999). Nebijokite drausminti vaiku. Vilnius: Tyto alba.

Saugaus vaiko centras. Prieiga per interneta: www.saugusvaikas.lt/programos.html

Slade, E. P., Wissow, L. S. (2004). Spanking in early childhood and later behavior problems: A prospective study of infants and young toddlers. Pediatrics, Vol. 113, 5, 1321-1330.

Smurtas prieš vaikus. Smurtas prieš moteris ir vaikus Lietuvoje. (1997). Vilnius. 
Straus, M. A. (1999). Is it time to ban corporal punishment of children? Canadian Medical Association Journal, Vol. 161, 821-829.

Šatas, J. (1999). Teisinès užkardos fizinėms bausmėms, taikomos vaikams šeimoje ir visuomeneje. Ar teisus stipresnis? Smurto prieš vaikus apžvalga Lietuvoje. Vilnius.

Tamošiūnienè, R. (1999). Vaiku nusikaltimai ir bausmès. Ar teisus stipresnis? Vilnius.

Vaiku linija. Prieiga per interneta: http://www.vaikulinija. lt/index.php/nustok/patycios/priezastys/

Vaitkienè, I. (2001). Fizinès bausmès Lietuviškoje šeimoje - tradicinis auklèjimo būdas. Smurtas prieš vaiką šeimoje ir visuomeneje. Klaipėda: Klaipėdos universiteto leidykla.

Valickas, G. (1993). Neigiami vertinimai, bausmès ir asmenybès formavimasis: Lietuvos švietimo reformos gairès. Vilnius.

Waterston, T. (2000). Giving guidance on child discipline. British Medical Journal, 1, 261-262.

Žukauskienè, R. (2001). Kodèl vaikai neklauso. Vilnius: LR ŠMM.

Снайдер, Р. (1994). Отказаться от репрессивного стиля воспитания. Семья и школа, 6, 14-15.

\title{
ADULTS' ATTITUDE TOWARDS CORPORAL PUNISHMENTS AS A PEDAGOGICAL MEANS CORRECTING BEHAVIOUR
}

\author{
Daiva Majauskienė, Jolanta Paulauskienè \\ Lithuanian Academy of Physical Education, Kaunas, Lithuania
}

\begin{abstract}
Adults have a lot of means to correct negative behaviour of a child. They can explain to the child patiently why his actions are wrong and what kind of behaviour they expect from their child or use various punishments without comments. In this study we will only deal with the discussion about corporal punishments because there is no unanimous opinion of scientists about the consequences of these punishments concerning the development of the child's personality while adults use them especially often to correct the child's behaviour.

The purpose of the study was to analyze adults' attitudes towards corporal punishments as pedagogical means correcting behaviour.

100 respondents (50 men and 50 women) were questioned. The sample was selected in a convenient way. We made up a questionnaire on the basis of the methodology used by the public opinion research centre and the market research centre "VILMORUS" to ask the inhabitants about violence against children (1999). The findings were processed applying methods of mathematical statistics. Reliability of the difference between the results obtained was estimated according to the criterion of the chi square $\left(\chi^{2}\right)$ which is used for checking hypotheses about distribution of variables in the population. The reliability level chosen is $\alpha=0.05$. The difference between the results was supposed to be meaningful if $\mathrm{p}<0.05$.

It was established that most parents used corporal punishments $(52 \%$ of fathers and $78 \%$ of mothers respectively) $(\mathrm{p}<0.05)$. We found that women had suffered from corporal punishments in their childhood more often than men. The tendency was noticed that corporal punishments as a means for the correction of the children's behaviour were chosen not so often at present. The respondents were punished by their parents in the childhood for disobedience, runaround, disappearance from home, lies. The main reasons why the respondents punished their children - runaround, disobedience, lies, poor marks, parents' bad mood. Almost one half of the respondents (58\% of men and $48 \%$ of women ) thought that corporal punishments helped to become a better person. $52 \%$ of men and $22 \%$ of women disagreed that corporal punishments were necessary in education. Only one third of the respondents (30\% of men and $28 \%$ of women) thought that corporal punishments should be forbidden by the law.
\end{abstract}

Keywords: correction of the behaviour, corporal punishment, reasons for using corporal punishments, consequences of corporal punishments.

Gauta 2007 m. birželio $11 \mathrm{~d}$.

Received on June 11, 2007

Priimta $2007 \mathrm{~m}$. rugsejjo $19 \mathrm{~d}$.

Accepted on September 19, 2007
Daiva Majauskienè

Lietuvos kūno kultūros akademija

(Lithuanian Academy of Physical Education)

Sporto g. 6, LT-44221 Kaunas

Lietuva (Lithuania)

Tel +3704635055

E-mail d.majauskiene@lkka.lt 